\section{Time of Nitrogen Application and Phosphorus Effects on Growth, Yield, and Fruit Quality of Pecan}

\author{
Michael W. Smith', Becky Cheary ${ }^{2}$, and Becky Carroll ${ }^{2}$ \\ Department of Horticulture and Landscape Architecture, Oklahoma State \\ University, Stillwater, OK 74078
}

Additional index words. Carya illinoinensis, cold injury, leaf analysis

\begin{abstract}
March vs. October $\mathrm{N}$ applications in factorial combination with two $\mathrm{P}$ rates were evaluated on two pecan [Carya illinoinensis (Wangenh.) C. Koch] cultivars. Leaf $\mathbf{N}$ concentrations were not affected by $\mathrm{N}$ application time. However, yield of 'Hayes' was increased during 4 of 7 years and cumulative yield was increased $37 \%$ when $N$ was applied during October compared to March. Yield of 'Patrick' and individual nut weight and kernel percentage of 'Hayes' and 'Patrick' were not affected by $\mathrm{N}$ application time. Phosphorus application increased leaf $P$ concentration 5 of 7 years during the study. Shoot growth, yield, individual nut weight, and kernel percentage were not affected by $P$ application.
\end{abstract}

Nitrogen is usually applied during February or March in Oklahoma pecan orchards. This application time is commonly used because few other activities during this period compete for the growers attention, and, historically, $\mathrm{N}$ applications during February or March have visibly benefitted the orchard with no observable adverse affects. Also, growers have targeted this period because ground covers are inactive, which may minimize competition for applied N. However, in many areas where pecans are native, late winter and spring flooding frequently prevents timely $\mathrm{N}$ application or may cause substantial loss of applied N. Therefore, alternative application times may be beneficial.

Although late winter or early spring are traditional times to apply $\mathrm{N}$ to fruit and nut trees, research on apple (Malus domestica Borkh.) and pear (Pyrus calleryana L.) indicates other application times are acceptable or, in some cases, superior. Fall $\mathrm{N}$ applications accelerated flower bud development and extended stigma receptivity and ovule longevity compared to spring $\mathrm{N}$ applications (HillCottingham, 1968; Williams, 1965). Apple fruit set was increased when $\mathrm{N}$ was applied during the fall rather than the spring (HillCottingham, 1968; Hill-Cottingham and Williams, 1967). However, others have reported no consistent relationship between application time and apple yield (Goode and Higgs, 1977). Taylor et al. (1975) reported $\mathrm{N}$ applied to pear in the spring was assimilated inefficiently compared to fall-applied N. They hypothesized that insufficient available carbo-

Received for publication 16 May 1994. Accepted for publication 23 Jan. 1995. Oklahoma Agricultural Experiment Station journal series no. J-6419. The cost of publishing this paper was defrayed in part by the payment of page charges. Under postal regulations, this paper therefore must be hereby marked advertisement solely to indicate this fact. ${ }^{1}$ Professor.

${ }^{2}$ Research Technician. hydrates in the spring prevented efficient $\mathrm{N}$ assimilation.

In pecan, Gammon and Sharpe (1955) reported growth was maximum when trees were fertilized $1 \mathrm{Feb}$. or earlier. They recommended fertilization during winter while the grass was dormant and offered the least competition. Hunter and Lewis (1942) evaluated several fertilizer application times on pecan. Application time did not affect yield, but nut quality was reduced when part of the fertilizer was applied during April or June. They speculated that additional growth stimulated by these application times competed with fruit development, thus reducing quality.

The optimum leaf concentration range for $\mathrm{P}$ in pecan is poorly defined. Several early studies failed to clearly determine the optimum $\mathrm{P}$ concentration range for growth, production, and fruit quality, primarily due to difficulties in obtaining substantial P absorption from soil applications (Alben and Hammar, 1964; Worley, 1974, 1977; Worley et al., 1974). To our knowledge, there are no reports of improved pecan yield, but two studies have reported $\mathrm{P}$ application improved kernel percentage (Hunter, 1951; Sparks, 1988). Most scientists working with pecan are using $0.12 \%$ as the minimum acceptable leaf $P$ concentration and from $0.19 \%$ to $0.3 \%$ as the maximum acceptable leaf P concentration (Smith, 1991). However, recent evidence supports a higher minimum acceptable $P$ concentration. Smith and Cotten (1985) reported that cold damage of 'Western' pecan decreased as leaf $\mathrm{P}$ concentrations increased from $0.11 \%$ to $0.17 \%$. Sparks $(1986,1988)$, based on greenhouse and field tests, suggested the minimum sufficiency level of $\mathrm{P}(0.12 \%)$ for pecan was too low. He found that maximum vegetative growth of greenhouse-grown pecan seedlings occurred when leaf $\mathrm{P}$ concentrations were $0.19 \%$ to $0.22 \%$. His field studies with adult trees showed that greatest fruit growth and minimum leaf scorch and defoliation occurred when leaf $\mathrm{P}$ was $>0.14 \%$ and $0.16 \%$, respectively.
This study evaluated the time of $\mathrm{N}$ application on selected performance characteristics of pecan. Additionally, applications of large quantities of $\mathrm{P}$ were evaluated to determine if increased leaf $\mathrm{P}$ concentrations could be achieved, and correlated with improved growth, yield, or fruit quality.

\section{Materials and Methods}

Our study, located at the Pecan Research Station near Sparks, Okla., was initiated in 1985 on 35-year-old 'Patrick' and 'Hayes' pecan trees. Trees were thinned to $22 /$ ha in 1984, leaving wide aisles for interplanting young pecan trees. This wide spacing served as a border between treatments. The soil was a port silt loam (fine-silty, mixed, thermic; Cumulic Haplustoll; Mollisols). Management included a closely mowed grass sod with 2-mwide, weed-free strips on each side of the tree, and pesticide applications recommended for commercial orchards in Oklahoma (Taylor et al., 1992; von Broembsen et al., 1992). Trees were not irrigated. The average budbreak date at this location is $15 \mathrm{Apr}$., and trees defoliate about 12 Nov.

Treatments were spring vs. fall $\mathrm{N}$ application in factorial combination with two P rates. Nitrogen $\left(\mathrm{NH}_{4} \mathrm{NO}_{3}\right)$ was either applied the second week of March or the first week of October each year from 1985 through 1992 at $112 \mathrm{~kg}$ N/ha. Nitrogen was uniformly broadcast from the trunk to the drip line. Phosphorus (triple superphosphate) was applied, with a drop-type spreader, during Mar. 1986 and again in May 1989 at $244 \mathrm{~kg} \mathrm{P} / \mathrm{ha}$ each application, from the trunk to $4 \mathrm{~m}$ beyond the drip line. Phosphorus and $\mathrm{N}$ applications were not incorporated. Each treatment combination was replicated four times. Sources of variation for the experimental design are shown in Tables 1 and 2. Data were tested using analysis of variance with Fisher's protected LSD.

Leaf samples were collected each year during July, using the middle pair of leaflets from the middle leaf on current-season's growth as the index tissue. Leaf samples were washed in distilled water, followed by a detergent wash (P-free detergent) then two distilled deionized water rinses. Samples were then dried at $80 \mathrm{C}$, ground to pass a 20-mesh (850$\mu \mathrm{m})$ screen, and stored in airtight glass jars until analysis. Nitrogen was determined using the macro-Kjeldahl method (Horowitz, 1980), and $\mathrm{P}$ was determined colorimetrically (Olsen and Sommers, 1982).

Soil samples were collected during Oct. 1989 and 1991 for $\mathrm{pH}$ and $\mathrm{P}$ analysis. Three samples were taken within the drip line of each tree at soil depths of 0 to $5 \mathrm{~cm}, 5$ to $15 \mathrm{~cm}$, and 15 to $30 \mathrm{~cm}$ in 1989 , and the same depths plus 30 to $45 \mathrm{~cm}$ in 1991. The three samples per tree were composited for each depth, mixed, and an aliquot taken for analysis. Soil $\mathrm{pH}$ was determined in a 1 water : 1 soil ratio and $\mathrm{P}$ extracted by Bray 1 solution with a 20 solution : 1 soil ratio and quantitated by the ascorbic acid color development method of Olsen and Sommers (1982).

Shoot length was measured and the num- 
Table 1. Sources of variation for leaf $\mathrm{N}$ and leaf $\mathrm{P}$ concentrations.

\begin{tabular}{|c|c|c|c|}
\hline \multirow[b]{2}{*}{ Source } & \multirow[b]{2}{*}{$\mathrm{df}$} & \multicolumn{2}{|c|}{ Sum of squares } \\
\hline & & Leaf $N$ & Leaf P \\
\hline$\overline{\text { Cultivar (C) }}$ & 1 & $1.6303^{* *}$ & $0.0018^{* * *}$ \\
\hline Block & 3 & $0.3312^{* *}$ & 0.0002 \\
\hline Error A & 3 & 0.0768 & 0.00011 \\
\hline Phosphorus (P) & 1 & 0.000004 & $0.0025^{*}$ \\
\hline Error B & 3 & 0.04168 & 0.00083 \\
\hline $\mathrm{C} \times \mathrm{P}$ & 1 & 0.0004 & 0.00008 \\
\hline Error C & 3 & 0.1989 & 0.00034 \\
\hline Nitrogen $(\mathrm{N})$ & 1 & 0.0372 & $0.0015^{* * *}$ \\
\hline $\mathrm{C} \times \mathrm{N}$ & 1 & 0.0007 & 0.0001 \\
\hline $\mathrm{P} \times \mathrm{N}$ & 1 & 0.0022 & 0.0001 \\
\hline $\mathrm{C} \times \mathrm{P} \times \mathrm{N}$ & 1 & 0.0299 & 0.000001 \\
\hline Error D & 12 & 0.3009 & 0.0007 \\
\hline Year (Y) & 6 & $2.9624^{* * * *}$ & $0.01340^{* * * *}$ \\
\hline $\mathrm{Y} \times \mathrm{C}$ & 6 & 0.1380 & $0.0013^{*}$ \\
\hline $\mathrm{Y} \times \mathrm{P}$ & 6 & 0.0405 & $0.0011^{*}$ \\
\hline $\mathrm{Y} \times \mathrm{N}$ & 6 & 0.1324 & 0.0005 \\
\hline $\mathrm{Y} \times \mathrm{C} \times \mathrm{P}$ & 6 & 0.1304 & 0.0003 \\
\hline $\mathrm{Y} \times \mathrm{C} \times \mathrm{N}$ & 6 & 0.0541 & 0.0011 \\
\hline $\mathrm{Y} \times \mathrm{P} \times \mathrm{N}$ & 6 & 0.0478 & 0.0002 \\
\hline $\mathrm{Y} \times \mathrm{C} \times \mathrm{P} \times \mathrm{N}$ & 6 & 0.2357 & 0.0006 \\
\hline Error E & 144 & 3.3718 & 0.0123 \\
\hline
\end{tabular}

Table 2. Sources of variation for shoot length, number of current-season shoots per 1-year-old shoot, yield, kernel percentage, and nut weight.

\begin{tabular}{|c|c|c|c|c|c|c|}
\hline \multirow[b]{2}{*}{ Source } & \multirow[b]{2}{*}{ df } & \multicolumn{5}{|c|}{ Sum of squares } \\
\hline & & $\begin{array}{l}\text { Shoot } \\
\text { length }\end{array}$ & $\begin{array}{c}\text { Shoots/ } \\
\text { 1-year-old } \\
\text { branch }\end{array}$ & Yield & $\begin{array}{c}\text { Kernel } \\
\text { percentage }\end{array}$ & $\begin{array}{c}\text { Nut } \\
\text { wt }\end{array}$ \\
\hline Cultivar (C) & 1 & $494.57^{* *}$ & 0.43 & $2009.78^{* *}$ & $443.53^{* *}$ & $16.73^{* *}$ \\
\hline Block & 3 & 9.05 & 0.34 & 246.26 & 40.30 & $7.42^{*}$ \\
\hline Error A & 3 & 27.78 & 0.40 & 170.80 & 21.57 & 0.37 \\
\hline Phosphorus (P) & 1 & $5.45^{*}$ & $0.37^{*}$ & 12.98 & 1.61 & 0.11 \\
\hline Error B & 3 & 1.30 & 0.03 & 31.39 & 2.55 & 0.41 \\
\hline $\mathrm{C} \times \mathrm{P}$ & 1 & 0.02 & 0.28 & 1.64 & 0.73 & 0.13 \\
\hline Error $\mathrm{C}$ & 3 & 8.04 & 0.31 & 49.99 & 14.12 & 0.016 \\
\hline Nitrogen $(\mathrm{N})$ & 1 & $17.56^{*}$ & 0.07 & 129.25 & 3.63 & 0.06 \\
\hline $\mathrm{C} \times \mathrm{N}$ & 1 & $36.09^{* *}$ & 0.16 & $269.07^{*}$ & 0.26 & 0.001 \\
\hline $\mathrm{P} \times \mathrm{N}$ & 1 & 1.68 & 0.01 & 26.11 & 0.68 & 0.001 \\
\hline $\mathrm{C} \times \mathrm{P} \times \mathrm{N}$ & 1 & 5.38 & 0.05 & 0.01 & 2.40 & 0.10 \\
\hline Error D & 12 & 27.71 & 1.55 & 366.83 & 38.22 & 2.34 \\
\hline Year (Y) & 5 & $88.70^{* * *}$ & $3.88^{* * * *}$ & $7161.67^{* * * *}$ & $1869.56^{* * * *}$ & $19.96^{* * * *}$ \\
\hline $\mathrm{Y} \times \mathrm{C}$ & 5 & 8.56 & $1.02^{*}$ & $1152.86^{* * *}$ & $92.86^{* * * *}$ & $3.36^{* *}$ \\
\hline $\mathrm{Y} \times \mathrm{P}$ & 5 & 16.69 & 0.11 & 33.58 & 17.62 & 0.30 \\
\hline $\mathrm{Y} \times \mathrm{N}$ & 5 & 26.28 & 0.25 & 133.86 & 0.49 & 8.53 \\
\hline $\mathrm{Y} \times \mathrm{C} \times \mathrm{P}$ & 5 & 3.36 & 0.22 & 33.31 & 2.18 & 0.34 \\
\hline $\mathrm{Y} \times \mathrm{C} \times \mathrm{N}$ & 5 & 28.09 & 0.47 & 65.83 & 9.96 & 0.24 \\
\hline $\mathrm{Y} \times \mathrm{P} \times \mathrm{N}$ & 5 & 6.84 & 0.17 & 5.81 & 8.39 & 0.73 \\
\hline $\mathrm{Y} \times \mathrm{C} \times \mathrm{P} \times \mathrm{N}$ & 5 & 15.19 & 0.63 & 69.82 & 17.58 & 1.17 \\
\hline Error E & 120 & 349.08 & 10.31 & 1491.89 & 357.55 & 22.93 \\
\hline
\end{tabular}

*,*,*** Significant at $P \leq 0.05,0.01$, or 0.001 , respectively.

ber of current-season shoots per 1-year-old branch was counted yearly during dormancy. Thirty 1-year-old branches located at the canopy periphery 6 to $7 \mathrm{~m}$ above ground were selected and the longest current-season shoot measured and the number of current-season shoots per branch counted on each tree.

Trees were harvested individually during November, nuts processed through a cleaner and weighed. Duplicate 10-nut samples, collected before cleaning, were weighed and cracked to determine weight per nut and kernel percentage.

Temperatures dropped to $-12 \mathrm{C}$ during 2 and 3 Nov. 1991. No freezing temperatures occurred before this sudden decrease, and several pecan cultivars were severely damaged. Four branches were collected from each tree during December, and cold injury was rated on 1-, 2-, and 3-year-old wood, where 1 greater than that of 'Hayes' $(2.38 \%)$. Phosphorus application did not affect leaf $\mathrm{N}$ concentration.

Soil P concentrations, sampled in 1989 and 1991, indicated that $\mathrm{P}$ application increased $\mathrm{P}$ concentrations from the surface through the 30-cm depth by 1989 and the 45cm depth by 1991 compared to the unfertilized treatment (Fig. 1). Phosphorus concentrations decreased as soil depth increased in fertilized and unfertilized plots, but the decline in $\mathrm{P}$ with sample depth was more dramatic in the Pfertilized plots. However, these data indicate that $\mathrm{P}$ had moved into the soil profile where large concentrations of roots were observed during soil sampling. Thus, absorption of $\mathrm{P}$ by the tree likely would not be limited by lack of $\mathrm{P}$ movement into areas of active roots. Soil $\mathrm{pH}$ was not significantly affected by $\mathrm{N}$ or $\mathrm{P}$ treatment or by soil depth (data not shown); soil pH averaged $\approx 6.3$ in 1989 and 1991 .

There were significant year $\times$ cultivar and year $\times \mathrm{P}$ treatment interactions affecting leaf $\mathrm{P}$ concentration (Table 1). The lowest leaf $\mathrm{P}$ concentration during the study was $0.122 \%$ during 1992 on 'Patrick' and the highest was $0.148 \%$ in 1988 , also on 'Patrick'. These concentrations are within normal ranges suggested for Oklahoma (Smith, 1991). Leaf P concentrations in 'Patrick' were higher than those of 'Hayes' during 4 years, and there were no significant differences in leaf $\mathrm{P}$ between cultivars the other 3 years (data not shown). Phosphorus application increased leaf $P$ in 5 of 7 years; however, differences in leaf $\mathrm{P}$ between treatments were small $(<0.012 \%)$. Leaf P concentrations were slightly higher when $\mathrm{N}$ was applied during the spring $(0.139 \%)$ than the fall $(0.134 \%)$.

There was a significant cultivar $\times \mathrm{N}$ application time interaction affecting shoot length (Table 2). Shoot growth of 'Hayes' $(7.7 \mathrm{~cm})$ was not affected by the $\mathrm{N}$ application time, but shoots of 'Patrick' were longer when fertilized in the spring $(11.7 \mathrm{~cm})$ than the fall $(10.2 \mathrm{~cm})$. We saw no new growth flushes during the fall as a result of the October $\mathrm{N}$ application. Phosphorus applications increased shoot length $(9.5$ $\mathrm{cm})$ compared to those not receiving $\mathrm{P}(9.1$ $\mathrm{cm})$.

A significant interaction was detected for the number of current-season shoots produced from each 1-year-old branch (1YOB) (Table 2). 'Hayes' (1.91 shoots/1YOB) produced more new shoots/1YOB than 'Patrick' (1.82 shoots/ 1YOB) during all years, except 1988 and 1991. Phosphorus application slightly increased the number of current-season shoots per $1 Y O B$ (1.91 vs. 1.82 shoots/1YOB). Nitrogen application time did not affect the number of new shoots/1YOB (data not shown).

There were significant interactions between year with cultivar and cultivar with $\mathrm{N}$ affecting yield (Table 2). Yield of 'Hayes' (13.0 kg/tree, 6-year average) was higher than that of 'Patrick' $(6.5 \mathrm{~kg} /$ tree) during 5 of the 6 years (data not shown). Nitrogen application time did not affect yield of 'Patrick'; however, yield of 'Hayes' was $10.9 \mathrm{~kg} /$ tree when fertilized during the spring and $14.9 \mathrm{~kg} /$ tree when fertilized during the fall. Cumulative yield of 'Hayes' 


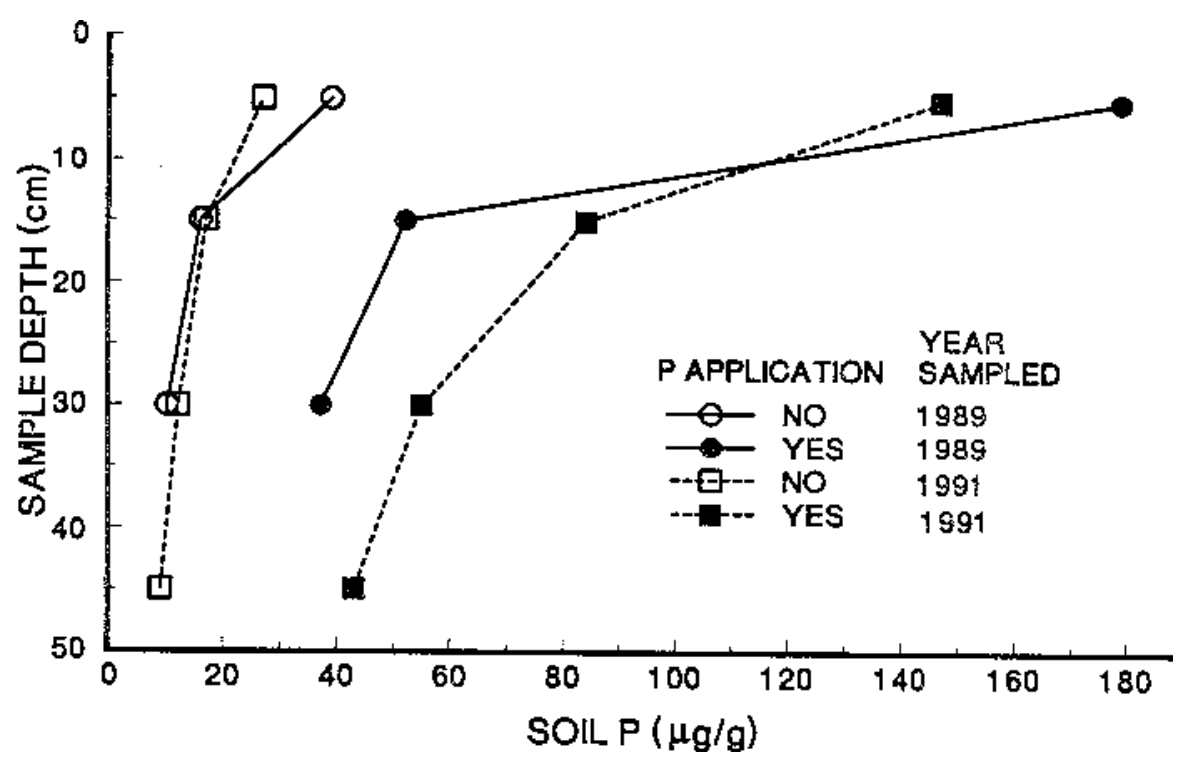

Fig. 1. Soil phosphorus distribution in 1989 and 1991 in fertilized and unfertilized plots following application of $244 \mathrm{~kg} \mathrm{P} / \mathrm{ha}$ during Mar. 1986 and May 1989. Means within each sample depth and year were significantly different, $P \leq 0.05$.

was $37 \%$ higher when $\mathrm{N}$ was applied during October compared to March.

A significant year $\times$ cultivar interaction was identified for both kernel percentage and nut weight (Table 2). 'Hayes' (4.25 g/nut; $54.8 \%$ kernel) produced a heavier nut with a lower kernel percentage than 'Patrick' ( $3.66 \mathrm{~g} /$ nut; $57.8 \%$ kernel) during most years. Neither $\mathrm{N}$ application time nor addition of $\mathrm{P}$ affected kernel percentage or nut weight (data not shown).

The amount of cold damage sustained by either cultivar was not affected by $\mathrm{N}$ application time or $\mathrm{P}$ application (data not shown). Cold damage ratings were 1.0 and 1.2 for 'Patrick' and 'Hayes', respectively. These ratings indicate that neither cultivar was appreciably damaged by the fall freeze, even though several other cultivars were severely damaged at this site (Smith et al., 1993).

\section{Discussion}

'Patrick' has a low yield potential relative to most commercial cultivars. In this study, yield of 'Patrick' was about half that of 'Hayes' Low yield of 'Patrick' compared to 'Hayes' may cause 'Patrick' to be insensitive to $\mathrm{N}$ application time. Nitrogen transport to the crop would be greater in 'Hayes' than in 'Patrick' and could create a late-season $\mathrm{N}$ deficiency in 'Hayes'. Thus, 'Hayes' would benefit from fall $\mathrm{N}$ application and 'Patrick' would not. Alternatively, leaf N concentrations, measured during July, were higher in 'Patrick' than in 'Hayes', although N application rates were the same. If $\mathrm{N}$ concentrations in 'Hayes' were low enough to inhibit flower initiation, and $\mathrm{N}$ concentrations in 'Patrick' were adequate for initiation, then fall applications would benefit only 'Hayes'. However, earlier research in Oklahoma with 'Western' suggested that $2.3 \%$ leaf $\mathrm{N}$ during July was adequate (Smith et al., 1985). In all years, except in 1990 and 1992, when excess water

Alben, A.O. and H.E. Hammar. 1964. Soil penetration and uptake of $\mathrm{P}$ and $\mathrm{K}$ in a 10-year NPK fertilizer experiment with Schley pecan trees. Soil Sci. 97:179-182.

Gammon, N., Jr., and R.H. Sharpe. 1955. Response of pecans to time and rates of nitrogen and potassium fertilization. Soil Sci. Soc. Fla. Proc. 25:124-129.

Goode, J.E. and K.H. Higgs. 1977. Effects of time of inorganic nitrogen fertilizers on apple trees in a grassed orchard. J. Hort. Sci. 52:317-334.
Hill-Cottingham, D.G. 1968. The effect of climate and time of application of fertilizers on the development and crop performance of fruit trees, p. 243-253. In: E.J. Hewitt and C.V. Cutting (eds.). Recent aspects of nitrogen metabolism in plants. Academic, New York.

Hill-Cottingham, D.G. and R.R. Williams. 1967. Effect of time of application of fertilizer nitrogen on the growth, flower development and fruit set of maiden apple trees, var. Lord Lambourne, and on the distribution of total nitrogen within the trees. J. Hort. Sci. 42:319-338.

Horowitz, W. 1980. Official methods of analysis of the association of analytical chemists. 13th ed. Assn. Offic. Anal. Chemists, Washington, D.C. p. 15 , section 2058.

Hunter, J.H. 1951. Progress report on soil management experiments with pecan. Proc. Southeast Pecan Growers' Assn. 41:10-17.

Hunter, J.H. and R.D. Lewis. 1942. Influence of fertilizer and time of its application on growth, yield, and quality of pecans. J. Amer. Soc. Agron. 34:175-187.

Olsen, S.R. and L.E. Sommers. 1982. Phosphorus, p. 404-430. In: A.L. Page, R.H. Miller, and D.R. Keeney (eds.). Methods of soil analysis. part 2. Chemical and microbiological properties. Amer. Soc. Agron. and Soil Sci. Soc. Amer., Madison, Wis.

Smith, M.W. 1991. Pecan nutrition, p. 152-158. In: B.W. Wood and J.A. Payne (eds.). Pecan husbandry: Challenges and opportunities. U.S. Dept. of Agr., Agr. Res. Serv., ARS-96.

Smith, M.W., P.L. Ager, and D.S.W. Endicott. 1985. Effect of nitrogen and potassium on yield, growth, and leaf elemental concentration of pecan. J. Amer. Soc. Hort. Sci. 110:446-450.

Smith, M.W., J.A. Anderson, and B.S. Parker. 1993. Cultivar and crop load influence cold damage of pecan. Fruit Var. J. 47:214-218.

Smith, M.W. and R.D. Bourne. 1989. Seasonal effects of flooding on greenhouse-grown seedling pecan trees. HortScience 24:81-83.

Smith, M.W. and B.C. Cotten. 1985. Relationship of leaf elemental concentrations and yield to cold damage of 'Western' pecan. HortScience 20:420-422.

Sparks, D. 1986. Growth and nutrition of pecan seedlings from potassium phosphate foliar sprays. HortScience 21:451-453.

Sparks, D. 1988. Growth and nutritional status of pecan in response to phosphorus. J. Amer. Soc. Hort. Sci. 113:850-859.

Taylor, B.K., B. van den Ende, and R.L. Canterford. 1975. Effects of rate and timing of nitrogen applications on the performance and chemical composition of young pear trees, cv. Williams' Bon Chretien. J. Hort. Sci. 50:29-40.

Taylor, G., G.V. Johnson, and M.W. Smith. 1992. Pecan insect and disease control-1992. Oklahoma State Univ. Ext. Facts 6232.

von Broembsen, S., S. Coppock, and G. Taylor. 1992. Pecan insect and disease control-1992. Oklahoma State Univ. Current Rpt. 6209.

Williams, R.R. 1965. The effect of summer nitrogen applications on the quality of apple blossom. J. Hort. Sci. 40:31-41.
Worley, R.E. 1974. Effect of N, P, K, and lime on yield, nut quality, tree growth, and leaf analysis of pecan (Carya illinoensis W.). J. Amer. Soc. Hort. Sci. 99:49-57.

Worley, R.E. 1977. Pecan leaf analysis: I. Varietal, fertilizer, and seasonal effects. Commun. Soil Sci. Plant Anal. 8:533-549.

Worley, R.E., S.A. Harmon, and R.L. Carter. 1974. Effect of repeated N, P, K, and lime applications on soil $\mathrm{pH}, \mathrm{P}$, and $\mathrm{K}$ under old and young pecan trees. J. Amer. Soc. Hort. Sci. 99:57-62.

HortScience, Vol. 30(3), June 1995 